\title{
Doenças emergentes, sistemas locais e globalização
}

Nos anos noventa, as doenças transmissíveis mais uma vez se tornaram uma prioridade de saúde ao nível mundial, contrariando a expectativa que prevaleceu durante a maior parte do século XX, de que tais doenças estavam sendo efetivamente controladas. Essa concepção linear explicitava-se no modelo da transição epidemiológica, que identificava o risco de morte por doenças transmissíveis e a alta prevalência de doenças endêmicas causadas por agentes infecciosos como atributos exclusivos do chamado "sub-desenvolvimento" sócio-econômico. A pandemia da AIDS foi o evento decisivo que obrigou a uma revisão dessa perspectiva. No entanto, outros sinais, como a disseminação da hepatite $\mathrm{C}$, o aumento da resistência de muitos agentes infecciosos aos antibióticos e o recrudescimento de diversas doenças endêmicas em áreas onde haviam sido controladas chamaram atenção para a necessidade de reconsiderar esta questão. Particularmente alarmante era a incapacidade dos sistemas de vigilância epidemiológica para a detecção precoce e contenção do HIV, revelando a vulnerabilidade das populações urbanas mesmo nos países desenvolvidos. Da mesma forma, o modelo epidemiológico tradicionalmente hegemônico, baseado na análise de fatores de risco individuais, mostrou-se inadequado para explicar ou prever a dinâmica deste processo infeccioso. A tradicional vigilância de fronteiras e as estratégias de controle sanitário já haviam-se mostrado incapazes de prevenir a disseminação internacional de parasitas e vetores, com impactos enormes sobre a economia e os ecossistemas.

A consolidação de uma nova ordem mundial, na qual a integração das economias de diferentes países tem sido acompanhada pelo rápido aumento da circulação de pessoas e mercadorias, resultou na desagregação de modos de vida tradicionais e na degradação ambiental. Dentro deste contexto apareceram propostas para uma epidemiologia das doenças emergentes e um sistema global de vigilância sanitária e de doenças.

Inicialmente as doenças emergentes apareceriam como um conceito impreciso ou um termo meramente gerencial cujo principal objetivo é o de nortear os programas de pesquisa e áreas de investimento. Tais propostas concentram-se fundamentalmente na aplicação de novos conhecimentos nos campos da biotecnologia e da informática. Devese enfatizar a necessidade de uma abordagem integrada às partes e ao todo, ao lugar e ao seu contexto globalizado, ao particular e ao general, embora isso nem sempre seja compreendido. Desta perspectiva, deve-se entender o binômio saúde/doença como um processo coletivo, recuperando o "lugar" como o espaço organizado para análise e intervenção, buscando identificar (para situações específicas) as relações entre as condições de saúde e seus determinantes culturais, sociais e ambientais, dentro dos ecossistemas modificados pelo trabalho humano, através de um enfoque inter-disciplinar. Para que isto ocorra, é essencial que a novidade emergente não seja considerada apenas como um atributo das populações de parasitas (de acordo com um viés biologicista), mas essencialmente como uma propriedade de ecossistemas complexos, em que as condições de estabilidade estão sendo produzidas e os riscos amplificados. Da mesma forma, os lugares devem ser vistos como sistemas organizados (não meramente comunidades isoladas), dinâmicos e complexos, com características únicas resultando de suas histórias.

Ao contrário da padronização dos métodos aplicados aos estudos epidemiológicos, a variedade de situações associadas com este problema requer o reconhecimento da necessidade de múltiplas abordagens teóricas e metodológicas. Quanto a isso, o acesso à informação torna-se imprescindível para o controle social, planejamento e segurança internacional, além de promover novos projetos de desenvolvimento em sistemas locais. Os artigos publicados neste suplemento dos Cadernos de Saúde Pública, resultado de um seminário realizado na Escola Nacional de Saúde Pública em novembro de 1999, representam uma contribuição à discussão sobre doenças emergentes e ecossistemas, com base numa combinação nova de trabalhos teóricos e estudos de caso internacionais.

Paulo Chagastelles Sabroza

Escola Nacional de Saúde Pública, Fundação Oswaldo Cruz
David Waltner-Toews

Department of Population Medicine, University of Guelph 


\section{Emerging diseases, local systems, and globalization}

In the 1990s, transmissible diseases once again became a global health priority, contrary to the expectation prevailing during most of the 20th century that such diseases were effectively being controlled. This linear conception had been made explicit in the epidemiological transition model, which identified the risk of death due to transmissible diseases and the high prevalence of endemic diseases caused by infectious agents as the exclusive characteristics of socio-economic "underdevelopment".

The AIDS pandemic was certainly the decisive event that mandated a review of this perspective. Yet other signs, like the dissemination of hepatitis $\mathrm{C}$, increased resistance to antibiotics by many infectious agents, and the increased occurrence of various endemic diseases in areas where they had previously been controlled all underscored the need to reconsider this issue. Particularly alarming was the incapacity of epidemiological surveillance systems for early detection and containment of HIV, thus revealing the vulnerability of urban populations even in the developed countries. Likewise, the traditionally hegemonic epidemiological model based on analysis of individual risk factors proved inadequate to explain or predict the dynamics of this infectious process. Conventional border surveillance and health control strategies had already proven incapable of preventing the international spread of parasites and vectors, with major impacts on economic production and ecosystems.

The consolidation of a new world order, in which the integration of economies from different countries has been accompanied by the increased circulation of both people and merchandise, has resulted in the breakdown of traditional ways of life and environmental degradation. Within this context, proposals have emerged for an epidemiology of emerging diseases and a global health/disease surveillance system.

Emerging diseases might initially appear to be an imprecise concept or a mere administrative term whose main objective is to orient research programs and investment areas. These proposals are essentially focused on the application of new knowledge in the fields of biotechnology and information technology. One should highlight the need for an integrated approach to the parts and the whole, the place and its globalized context, the particular, and the general, even though this is not always understood. From this perspective, one must once again understand the health/disease pair as a collective process and recover the "place" as an organized space for analysis and intervention, seeking to identify (for specific situations) the relations between health conditions and their cultural, social, and environmental determinants, within the ecosystems modified by human labor, through an interdisciplinary focus. In order for this to actually happen, it is essential that emerging novelty not be considered merely an attribute of parasite populations (according to a biologistic bias), but essentially a property of complex ecosystems, where conditions for instability are being produced and risks amplified. Likewise, places should be understood as organized systems (not merely isolated communities), dynamic, and complex systems with unique characteristics resulting from their particular histories.

Contrary to the standardization of methods applied to epidemiological studies, the variety of situations associated with this problem mandates recognition of the need for multiple theoretical and methodological approaches. In this regard, access to information becomes indispensable for social control, planning, and international security, and can also foster new strategies for development projects in local systems. The articles published in this thematic issue of Cadernos de Saúde Pública, resulting from a seminar held at Escola Nacional de Saúde Pública in November 1999, are a contribution to the discussion on emerging diseases and ecosystems based on a new combination of theoretical papers and international case studies.

Paulo Chagastelles Sabroza

Escola Nacional de Saúde Pública, Fundação Oswaldo Cruz
David Waltner-Toews

Department of Population Medicine, University of Guelph 